\title{
Education and Health Status of Child Workers of Dhaka City
}

\section{Madiha Khan}

Lecturer, Department of Economics, Southeast University, Dhaka, BANGLADESH

\begin{abstract}
Children are the future of the country. Every child has the right to grow up in the right way. But it is a matter of great regret that child labor is highly prevalent in this country, and all child workers are deprived of their rights. Child workers are engaged in various types of works in Bangladesh. Many of the jobs that children perform in this country are considered hazardous and put their physical and mental development at risk. Child labor is work that deprives children of a childhood and affects their health and education. So, the government should take effective steps to withdraw children from hazardous jobs and offer incentives to attend school and improve law enforcement to eliminate child labor.
\end{abstract}

Keyword: Child worker, Education, Health

JEL Classification Code: J13; I18; K32

\section{INTRODUCTION}

The word 'child' usually indicates the human being that is an innocent and dependent one. Children are taken care of and protected by the elders, especially by parents. Age limits formally regulate child's activities. There is a wide variation in the definition of 'child' and 'child labor.' It also differs from country to country and even from activity to activity within a country. Bangladesh is a unique example of this variation. The Factory Act of 1965 set the minimum age at 12, the Employment of Children Act of 1938 set it at 15, the Children Act of 1974 defined 'child' as a person under the age of 16 years (Khan, 2001). According to ILO, child labor is an economic activity conducted by a person below the age of 15 . In Bangladesh, the primary education begins at the age of six and lasts for five years (1 to 5). Generally, the secondary education starts at the age of 10 and lasts for five years for the Secondary School Certificate (SSC), before proceeding to the Higher Secondary Certificate (HSC) for another two years. In the light of ILO Convention No. 138, the minimum age for admission to employment or work shall not be less than the age of completion of compulsory schooling (normally not less than 15 years). According to the Social Work Dictionary (1995), it is paid or forced employment of children who are younger than a legally defined age. The minimum age for employment may vary from ages 14 to 18 depending on the nature of the work and the child labor standards of the country in which it takes place. According to National Children Policy of Bangladesh, 'Boys and girls under 14 years of age will be considered as children' (MOWCA, 1994). This definition will be the operational 
definition of 'child' used in this study and the term 'child labor' will refer to the children involved in economic activities, which were covered with this study.

\section{OBjectives OF THE Study}

The objective of this study is to investigate and analyze the impact of child labor in Bangladesh on their health and education. Moreover, the objective of the study is to recommend the government of Bangladesh to take necessary actions and effective steps to establish children rights and solve the problems arising from child labor so that all the children in Bangladesh get their right of protection against any type of exploitation.

\section{Methodology OF THE Study}

The methodology of the study is based on the primary as well as secondary data. The study mainly depends on primary data collected through a well framed and structured questionnaire to elicit the well considered opinions of the respondents. Secondary data have been collected for this study from different published and unpublished documents such as books, research reports, journals, articles, laws, rules posters and internet.

\section{Sample and Data Collection}

Seventy-nine respondents from child labor force who were engaged in various types of activities like working at roadside tea stalls or hotel, working as a transport helper or engaged in domestic work, etc. have been considered for collecting data. The primary data has been drawn from two main survey instruments; these are questionnaire (formal interview) and field observation. The study area was different locations in Dhaka city and the survey was done in November-December, 2013.

\section{Status OF ChILD WoRKers in BANGLADESH}

Of the total child population, $17.5 \%$ or 7.4 million children are engaged in economic activities. $77.8 \%$ percent of the child workers is from the rural areas of Bangladesh (BBS, 2003). 10.1\% of children between age 5 and 14 are in the workforce and another $6.8 \%$ between age 7 and 14 who besides going to school also work in Bangladesh. (OCFT, 2011). According to National Children Policy (1994), boys and girls under 14 years of age are considered as children in Bangladesh (MOWCA, 1994). So this study covers children up to 14 years.

Table I: Distribution of child laborers by age and sex $(\mathrm{N}=79)$

\begin{tabular}{|c|c|c|c|}
\hline \multirow{2}{*}{ Sex } & \multicolumn{3}{|c|}{ Percentage of Children } \\
\cline { 2 - 4 } & Male & Female & Total \\
\hline 5-8 years & 13.92 & 0.00 & 13.92 \\
\hline 8-11years & 25.32 & 6.33 & 31.65 \\
\hline 11-14 years & 36.71 & 17.72 & 54.43 \\
\hline Total & 75.95 & 24.05 & 100 \\
\hline
\end{tabular}

Source: Field survey, November-December, 2013.

It is revealed from the Table I that a huge number of children in the age group between 1114 years $(54.43 \%)$ were engaged in the economic activities. The findings have also showed that even at the age of below 8 years some children were involved in economic activities who were boys and the average age of the child workers was 11.19 years with the standard deviation of 2.38 . 
Table II: Distribution of child workers by person(s) with stay

\begin{tabular}{|c|c|c|}
\hline Person(s) with Stay & Frequency & Percentage \\
\hline With Parents & 35 & 44.30 \\
\hline With father & 6 & 7.59 \\
\hline With Mother & 30 & 37.97 \\
\hline With Relatives or Others & 8 & 10.13 \\
\hline Total & 79 & 100 \\
\hline
\end{tabular}

Source: Field survey, November-December, 2013.

From the Table II, it is found that $44.30 \%$ child workers stayed with their parents. But all of them were not lucky enough to live with their parents. Another $7.59 \%$ of child workers stayed only with their father and $37.97 \%$ of child workers stayed only with their mother. About $10 \%$ of child workers stayed with their relatives or stayed at their work places without any family members. Child workers who live away from their families may be in such situations where they are exposed to violence, abuse and economic exploitation. Child Labor Force Survey (CLS) findings revealed that a higher proportion of working children belong to the larger size households. In this study, it is found that family size is big in the majority of cases; about $92 \%$ of child worker has the household size more than 4 members. So there is no significant difference between empirical findings of this study and national findings.

\section{Educational Status}

Human resources development is very important for any country, especially for a poor country and its children and women, though it is a global issue. One of the main indicators of human resource development is education. In Bangladesh, about 34 per cent of preschool age children are not in school. The rate of exclusion is lower for primary school-age children at 16.2 percent but rises sharply for lower secondary school-age children at 30.7 percent (UNICEF, 2014).Child workers of Bangladesh are joining the labor market under compulsion without proper education and adequate training. The following table 1.3 shows the level of education of child workers by sex.

Table III: Distribution of child farm workers by education level and sex

\begin{tabular}{|c|c|c|c|c|}
\hline \multirow[t]{2}{*}{ Education level } & & \multicolumn{2}{|c|}{ Sex } & \multirow[t]{2}{*}{ Total } \\
\hline & & Male & Female & \\
\hline Class 1-2 & $\begin{array}{c}\text { Count } \\
\% \text { of total }\end{array}$ & $\begin{array}{c}3 \\
3.80\end{array}$ & $\begin{array}{c}3 \\
3.80\end{array}$ & $\begin{array}{c}6 \\
7.59\end{array}$ \\
\hline Class 3-4 & $\begin{array}{c}\text { Count } \\
\% \text { of total }\end{array}$ & $\begin{array}{c}19 \\
24.05\end{array}$ & $\begin{array}{c}4 \\
5.06\end{array}$ & $\begin{array}{c}23 \\
29.11\end{array}$ \\
\hline Class 5-6 & $\begin{array}{c}\text { Count } \\
\% \text { of total }\end{array}$ & $\begin{array}{c}11 \\
13.92\end{array}$ & $\begin{array}{c}0 \\
0.00\end{array}$ & $\begin{array}{c}11 \\
13.92\end{array}$ \\
\hline Can sign name & $\begin{array}{c}\text { Count } \\
\% \text { of total }\end{array}$ & $\begin{array}{c}7 \\
8.86\end{array}$ & $\begin{array}{c}1 \\
1.27\end{array}$ & $\begin{array}{c}8 \\
10.13\end{array}$ \\
\hline Illiterate & $\begin{array}{c}\text { Count } \\
\% \text { of total }\end{array}$ & $\begin{array}{c}20 \\
25.32\end{array}$ & $\begin{array}{c}11 \\
13.92\end{array}$ & $\begin{array}{c}31 \\
39.24\end{array}$ \\
\hline Total & $\begin{array}{c}\text { Count } \\
\% \text { of total }\end{array}$ & $\begin{array}{c}60 \\
75.95\end{array}$ & $\begin{array}{c}19 \\
24.05\end{array}$ & $\begin{array}{c}79 \\
100\end{array}$ \\
\hline
\end{tabular}

Source: Field survey, November-December, 2013. 
From the Table III, it is found that about $39 \%$ of child workers were illiterate. All survey result clearly indicates that a good number of working children were not attending to school. The empirical findings have revealed that the level of education was not good among the child workers.

It is also very much necessary to see that how many child workers is still continuing education. The table 1.4 shows the status of child workers in case of continuing the education.

Table IV: Distribution of child farm workers by status of continuing education

\begin{tabular}{|c|c|c|}
\hline Present status & Frequency & Percentage \\
\hline Continuing & 31 & 39.24 \\
\hline Not continuing & 15 & 18.99 \\
\hline Never attend school & 33 & 41.77 \\
\hline Total & 79 & 100 \\
\hline
\end{tabular}

Source: Field survey, November-December, 2013.

It is revealed from the Table IV that about $39 \%$ of child workers were continuing their studies and about $19 \%$ had dropped out. Here it should be noticed that about $42 \%$ of child workers never attended to school.

\section{Health Status}

Health is a state of physical, mental and social well-being and the absence of disease. One of the important indicators of human resource development is good health. As today's children are the leaders of tomorrow so, all the children have the right to have a sound health and get proper treatment.

\section{Treatment during sickness:}

According to Khan (2001), about $64 \%$ of child workers of Dhaka city received treatment from dispensary/medicine shops, which means without consulting a doctor they are taking medicine.

Table V: Distribution of child farm workers by treatment

\begin{tabular}{|c|c|c|}
\hline Treatment from & Frequency & Percentage \\
\hline Government hospital & 11 & 13.92 \\
\hline Homeopathy & 33 & 41.77 \\
\hline Medicine shop & 5 & 6.33 \\
\hline Kabiraj & 14 & 17.72 \\
\hline Ojha/Fakir & 16 & 20.25 \\
\hline Total & 79 & 100 \\
\hline
\end{tabular}

Source: Field survey, November-December, 2013.

From the Table V, it is found that in case of sickness the child workers were getting some treatment. The table shows that about $42 \%$ of child workers received homeopathy treatment. However, about $21 \%$ were receiving treatment from ojha or fakir and $18 \%$ were receiving treatment by Kabiraj and about $14 \%$ were going to the government hospital for treatment. Here we see that homeopathy treatment is popular among the child workers because it is cheaper. 


\section{Taking vaccination:}

It is very much positive that most of the working children in this study had heard about the Expanded Program on Immunization (EPI) though all were not found to take all necessary vaccination. In many cases, they took only one or two vaccination, which is not enough to protect against the six deadly diseases.

Table VI: Distribution of child farm workers by taking vaccination and sex

\begin{tabular}{|c|c|c|c|}
\hline \multirow{2}{*}{ Vex } & \multicolumn{3}{|c|}{ Percentage } \\
\cline { 2 - 4 } & Male & Female & Total \\
\hline Polio & 26.58 & 13.92 & 40.50 \\
\hline Tetanus & 6.33 & 1.27 & 7.60 \\
\hline BCG & 5.06 & 0.00 & 5.06 \\
\hline Whopping cough & 0.00 & 1.27 & 1.27 \\
\hline Measles & 5.06 & 1.27 & 6.33 \\
\hline Only two & 8.86 & 0.00 & 8.86 \\
\hline Only three & 3.78 & 0.00 & 3.78 \\
\hline All & 5.06 & 3.80 & 8.86 \\
\hline None & 15.19 & 2.53 & 17.72 \\
\hline Total & 75.92 & 24.06 & 100 \\
\hline
\end{tabular}

Source: Field survey, November-December, 2013.

It is revealed from the Table VI that, about $18 \%$ of child workers did not take any vaccination. Some respondents among those who did not take any vaccination mentioned that they did not take the vaccination because in most of the cases parents did not know or failed to obtain the opportunity. This means that many of them were aware of the necessity of vaccination but they did not take it, which carries similar value as those who had not heard of the EPI at all. Only about $9 \%$ of child workers took all the vaccination, and the percentage is very poor.

\section{Sources of water supply and use:}

In this study we find that most of the working children have little access to modern sanitation facilities. About $49 \%$ of child workers use the Kacha latrine that was made by digging a big hole in the ground and putting something to sit over it. This type of latrine is unhygienic and harmful to health and environment. Access to pure water is necessary to maintain health and environment safe. The following table 1.7 shows the sources of water for different types of use.

Table VII: Sources of water for different types of use

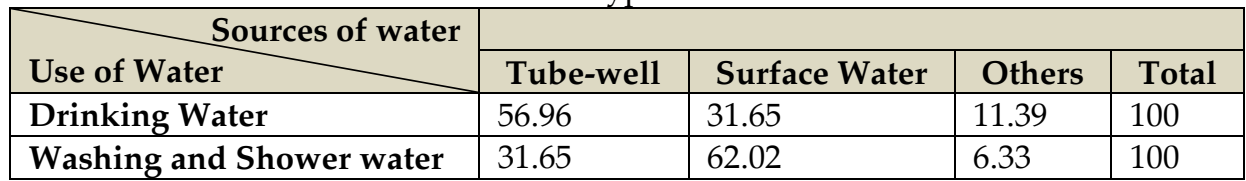

Source: Field survey, November-December, 2013.

From the Table VII, it is found that the public water supply, which is safest, did not reach in all the area adequately. About 57\% working children used water of tube-well for drinking purpose, which is considered safe (it is fresh in that sense) for health. About $62 \%$ working children used the surface water for shower and washing purposes. 


\section{Knowledge about child rights of child workers:}

Knowledge about child rights is very much related to the level of education. But unfortunately millions of children are reported not to attend the school. Many child workers miss out on their right to education because they do not have the time to go to school or to study. In view of the present socio-economic conditions of Bangladesh, they are fighting for survival. But in the human society all children have the right to be protected against any type of exploitation.

Table VIII: Distribution of child workers by knowledge about child rights and education

\begin{tabular}{|c|c|c|c|c|c|c|c|}
\hline \multirow{2}{*}{$\begin{array}{l}\text { Knowledge } \\
\text { about child } \\
\text { rights }\end{array}$} & & \multicolumn{5}{|c|}{ Education level } & \multirow{2}{*}{ Total } \\
\hline & & $\begin{array}{c}\text { Class } \\
1-2\end{array}$ & $\begin{array}{c}\text { Class } \\
3-4\end{array}$ & $\begin{array}{c}\text { Class } \\
5-6\end{array}$ & $\begin{array}{c}\text { Can } \\
\text { sign } \\
\text { name }\end{array}$ & Illiterate & \\
\hline Yes & $\begin{array}{c}\text { Count } \\
\% \text { of total }\end{array}$ & $\begin{array}{c}0 \\
0.00\end{array}$ & $\begin{array}{c}7 \\
8.86\end{array}$ & $\begin{array}{c}9 \\
11.39\end{array}$ & $\begin{array}{c}3 \\
3.80\end{array}$ & $\begin{array}{c}1 \\
1.27\end{array}$ & $\begin{array}{c}20 \\
25.32\end{array}$ \\
\hline No & $\begin{array}{c}\text { Count } \\
\% \text { of total }\end{array}$ & $\begin{array}{c}6 \\
7.59\end{array}$ & $\begin{array}{c}16 \\
20.25\end{array}$ & $\begin{array}{c}2 \\
2.53\end{array}$ & $\begin{array}{c}5 \\
6.33\end{array}$ & $\begin{array}{c}30 \\
37.97\end{array}$ & $\begin{array}{c}59 \\
74.67\end{array}$ \\
\hline Total & $\begin{array}{c}\text { Count } \\
\% \text { of total }\end{array}$ & $\begin{array}{c}6 \\
7.59\end{array}$ & $\begin{array}{c}23 \\
29.11\end{array}$ & $\begin{array}{c}11 \\
13.92\end{array}$ & $\begin{array}{c}8 \\
10.13\end{array}$ & $\begin{array}{c}31 \\
39.24\end{array}$ & $\begin{array}{c}79 \\
100\end{array}$ \\
\hline
\end{tabular}

Source: Field survey, November-December, 2013.

It is revealed from the Table VIII that, only about $25 \%$ of child workers had some knowledge about child rights. The findings also indicate that knowledge about child rights is very much related to the level of education. About $82 \%$ of child workers who were the students of class 5-6 know about the child rights. They gathered it from their school and rally during the children week.

\section{EXPECTATIONS OF CHILD WORKERS}

It is widely admitted that food, cloth, shelter, education are rights for the children but many studies find that most of the child workers expectation is to work and get education together.

Table IX: Expectations of Child Workers

\begin{tabular}{|c|c|c|}
\hline Expectations & & Total \\
\hline Only education & $\begin{array}{c}\text { Count } \\
\% \text { of total }\end{array}$ & $\begin{array}{c}12 \\
1519\end{array}$ \\
\hline $\begin{array}{c}\text { Education and } \\
\text { work }\end{array}$ & $\begin{array}{c}\text { Count } \\
\% \text { of total }\end{array}$ & $\begin{array}{c}43 \\
54.43\end{array}$ \\
\hline Small business & $\begin{array}{c}\text { Count } \\
\% \text { of total }\end{array}$ & $\begin{array}{c}22 \\
27.85\end{array}$ \\
\hline Others & $\begin{array}{c}\text { Count } \\
\% \text { of total }\end{array}$ & $\begin{array}{c}2 \\
2.53\end{array}$ \\
\hline Total & $\begin{array}{c}\text { Count } \\
\% \text { of total }\end{array}$ & $\begin{array}{c}79 \\
100 \\
\end{array}$ \\
\hline
\end{tabular}

Source: Field survey, November-December, 2013.

From the Table IX, it is found that about $54 \%$ child workers expectation was to work and get education together and only about $15 \%$ of child workers wanted only education and about $28 \%$ child workers wanted to see them as small businessmen in the future. 


\section{Opinion of child farm workers about child labor:}

During this survey I also tried to get the opinion of children about child labor. The table 1.10 shows the distribution of child workers by opinions to stop/deal child labor.

Table X: Distribution of child farm workers by opinion to stop/deal child labor

\begin{tabular}{|c|c|c|}
\hline Opinion & Frequency & Percentage \\
\hline No idea & 14 & 17.72 \\
\hline Poverty reduction & 39 & 49.37 \\
\hline Government initiatives & 15 & 18.99 \\
\hline Enhance educational facilities and financial help & 8 & 10.13 \\
\hline Others* & 3 & 3.80 \\
\hline Total & 79 & 100 \\
\hline
\end{tabular}

Source: Field survey, November-December, 2013.

* Others include providing food and dress in school and creation of awareness among the parents.

From the Table $X$, it is found that, about $18 \%$ child workers had no idea about how to stop or deal with child labor in Bangladesh. About $49 \%$ of child workers gave importance about the poverty reduction and about $19 \%$ of them gave their opinion that if government takes serious initiatives then it is possible to stop the child labor. Although the data covered a limited population in this study, but there are indications that almost all the child workers are not in a good position in terms of health and education level.

\section{RECOMMENDATIONS}

- There is a lack of adequate statistics on child labor in Bangladesh. To determine the nature of child labor a regular and comprehensive survey is necessary. Some features on child labor can be included in the questionnaire of the national census.

- Learning through earning should be the focus for special schools for working children where food or tiffin, dress and stipend will be provided. The school hours will be fixed in accordance with the working time of child workers.

- Guardians of child workers are not aware of laws and child rights. Government should promote awareness of child labor issues nationwide with the help of NGOs and media in the general community. This awareness raising campaign may be introduced in the schools including special schools for working children.

- In this study, it is found that children of migrant household less likely to be received all vaccination. One possible reason for this may be a higher opportunity cost of time for migrant parent/parents, and periods where one or both parents are absent from the children. In this case both government and NGOs can introduce the door-to-door vaccination services especially in slum and rural areas.

\section{Conclusion}

This study is an attempt to understand and interpret the negative impacts of child labor on education and health of the children. The empirical findings obtained from the field survey are used to analyze the status of child workers who engaged in different economic activities. Health status of child workers is very important. The national surveys in this field did not cover the working children separately. This study also has some limitations; further research on this particular topic can improve the total welfare of working children in Bangladesh. But this study has revealed that about half of the child workers have no access to primary health care. Often they are treated by medicine directly taken from a 
medicine shop without consulting a doctor or they go to Kabiraj or fakir during sickness. As a result they remain half treated or untreated. Primary education is free and compulsory in Bangladesh but it is found that normal schools are not suitable for child workers. The empirical result has revealed that about two-fifth of child workers are illiterate. The empirical finding has revealed that male child workers are more numerous than female child workers. This study has also found out that children are much more likely to work when they live in a household where the potential income generation is low or where this potential has already been used up. The ministry of Labor and Employment has adopted a national Child Labor Elimination Policy, which provides a framework to eradicate all forms of child labor by 2015 in Bangladesh. So, we can hope to build a country where all the children get their right of protection against any type of exploitation.

\section{REFERENCES}

Ashagrie, K. 1997. Statistics on Child Labor: A Brief Report. Bulletin of Labor Statistics, ILO, Geneva, pp. 2-5.

Barker, B. 1995. The Social Work Dictionary. Washington DC, USA, 55 pp.

BBS. 2003. Progotir Pathey. Ministry of Planning, GOB, Dhaka, Bangladesh.

Bhalotra, S. and Heady, C. 2000. Child Farm Labour: Theory and Evidence. Mimeograph, Cambridge, UK, $41 \mathrm{pp}$.

ILO. 1998. Child Labour in Asia. Regional Department for Asia and the Pacific, Geneva.

ILO. 2005. Bangladesh Baseline Survey on Child Labor Situation in Construction Industry in Narayanganj and Munshiganj Districts

Khan, M.A. 1998. Shramo Kallyan O Shilpo Samparko (Labour Welfare and Indutrial Relations). Dhaka, Bangladesh.

Khan, M.A. 2001. Child Labour in Dhaka City. Dhaka, Bangladesh, 31 pp.

Rahman, W. 1997. Child Labour Situation in Bangladesh: A Rapid Assessment. ILO \& UNICEF, Dhaka, Bangladesh, $44 \mathrm{pp}$.

Salmon, C. 2005. Child Labour in Bangladesh: Are Children the Last Economic Resources of the Household. Sage Publication, University of Savoie, France, pp. 44-45.

UNDP. 2011. Sustainability and Equity: A better future for all, human development report, New York.

UNICEF. 2013. Global Initiative on Out-of-School Children: Bangladesh Country Study, Dhaka, Bangladesh 